\title{
DISTRIBUTION OF GONGRINE AND GIGARTININE IN MARINE ALGAE
}

\author{
Keiji Iтo*, Keisuke Mryazawa**, and Yoshiro Hashimoto** \\ (Received May 30, 1966)
}

In the previous publications ${ }^{1,2}$, ITo and HASHIMoTo reported on the occurrence of two guanylurea derivatives, named gongrine and gigartinine, in a red alga, Gymnogongrus fabelliformis. These substances were isolated and postulated to be $\gamma$-(guanylureido) butyric acid and L- $\alpha$-amino- $\delta$-(guanylureido) valeric acid, respectively.

The distribution of these guanylurea derivatives and free arginine was surveyed by paper chromatography, and the results are presented in this paper.

\section{Experimental}

\section{Materials}

Specimens were collected at the intertidal region of Hayama and Jōga-Shima, Kanagawa Prefecture in January, March and May 1965. The fresh seaweeds were roughly washed with water and air-dried. The dried materials were then powdered and preserved in a desiccator.

\section{Preparation of the test solution for paper chromatography}

Twenty grams of dried algal powder were extracted twice with a $100-\mathrm{ml}$ portion of hot $75 \%$ ethanol and the extracts were concentrated in vacuum to $20 \mathrm{ml}$. After being decolorized with ether, the solution was passed through a column of Dowex $50 \mathrm{X}-8\left(10 \times 2.0 \mathrm{~cm}, 50 \sim 100 \mathrm{mesh}, \mathrm{H}^{+}\right)$. From the column washed with water the adsorbed fraction was eluted with $2 \mathrm{~N}$ aqueous ammonia, until the ninhydrin test indicated the complete elution. The eluate freed from ammonia was made up to $2 \mathrm{ml}$ with water, and subjected to paper chromatography.

\section{Paper chromatography}

By the ascending method, the extracts were run on Toyo-roshi No. $50(2 \times 40 \mathrm{~cm})$ in a solvent, $n$-butanol-pyridine-acetic acid-water $(4: 1: 1: 2)$, and developed by the Sakaguchi reagent ${ }^{3 !}$ consisting of $0.1 \% \alpha$-naphthol in $\mathrm{N} \mathrm{NaOH}$ and $5 \%$ sodium hypochlorite solution. The $R_{f}$ values for arginine, gongrine and gigartinine were $0.24,0.70$ and 0.32 , respectively. Gongrine and gigartinine gave a specific orange color, clearly differing from the pink one given by arginine, and this facilitated characterization of these compounds.

\footnotetext{
* Faculty of Fisheries and Animal Husbandry, Hiroshima University, Fukuyama, Hiroshima.

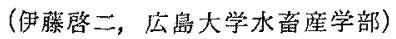

** Laboratory of Fisheries Chemistry, Faculty of Agriculture, The University of Tokyo, Tokyo.（宮沢辟輔・橋本芳郎，東京大学牟学部）
} 


\section{Results and Discussion}

As summarized in Table 1, twenty-five species of algae were investigated. In green and brown algae any appreciable quantity of both gongrine and gigartinine is not detected, except one species of brown alga, Colpomenia sinuosa, which shows a doubtful spot of gigartinine. In red algae, gigartinine is widely distributed, whereas gongrine is limited to a few species. The former is found in a fairly high concentration in the following seven species, Gelidium amansii, Grateloupia livida, Polyopes polyideoides, Carpopeltis flabellata, Hypnea japonica, Gracilaria textorii and Gymnogongrus flabelliformis. The latter, on the other hand, is detected in Grateloupia livida collected in May, Carpopeltis flabellata in March and Gracilaria textorii in a

Table 1. Distribution in marine algae of the substances positive for Sakaguchi's reagent.

\begin{tabular}{|c|c|c|c|c|c|}
\hline & $\begin{array}{l}\text { Date of } \\
\text { collection }\end{array}$ & Arginine & Gigartinine & Gongrine & $\begin{array}{c}R_{f} \text { of } \\
\text { unknown } \\
\text { substances }\end{array}$ \\
\hline \multicolumn{6}{|l|}{ Green algae: } \\
\hline Monostroma sp. & Mar. & - & - & - & \\
\hline Enteromorpha prolifera & Mar. & - & - & - & \\
\hline Codium adhaerens & Mar. & + & - & - & \\
\hline \multicolumn{6}{|l|}{ Brown algae: } \\
\hline Padina arborescens & Mar. & - & - & - & \\
\hline Ishige okamurai & Jan. & + & - & - & \\
\hline Colpomenia sinuosa & Mar. & + & \pm & - & \\
\hline Hizikia fusiforme & Jan. & ++ & - & - & \\
\hline Sargassum horneri & Jan. & + & - & - & \\
\hline Sargassum ringgoldianum & Jan. & ++ & - & - & \\
\hline Sargassum thunbergii & Mar. & + & - & - & \\
\hline \multicolumn{6}{|l|}{ Red algae: } \\
\hline Gelidium amansii & Jan. & + & ++ & - & \\
\hline Grateloupia elliptica & May & + & - & - & 0.19 \\
\hline Grateloupia liviala & $\begin{array}{l}\text { Jan. } \\
\text { May }\end{array}$ & + & $\begin{array}{l}++ \\
++\end{array}$ & $\bar{t}$ & 0.58 \\
\hline Polyopes polyideoides & Jan. & + & +++ & - & \\
\hline Carpopeltis affinis & Jan. & \pm & \pm & - & \\
\hline Carpopeltis flabellata & $\begin{array}{l}\text { Mar. } \\
\text { May }\end{array}$ & \pm & $\begin{array}{c}t+ \\
\pm\end{array}$ & \pm & 0.41 \\
\hline Hypnea japonica & Jan. & + & ++ & - & \\
\hline Gracilaria gigas & Mar. & + & - & - & \\
\hline Gracilaria incurvata & Mar. & - & - & - & \\
\hline Gracilaria textorii & Jan. & + & $+t+$ & + & 0.47 \\
\hline Gymnogongrus flabelliformis & May & + & ++ & $+t+$ & 0.53 \\
\hline Ahnfeltia concinna & Jan. & - & - & - & \\
\hline Gigartina tenella & Mar. & + & - & - & \\
\hline Chondrus ocellatus & Mar, & - & - & - & \\
\hline Laurencia sp. & Mar. & \pm & - & - & \\
\hline
\end{tabular}


small quantity respectively, and in G. flabelliformis at an exceptionally high level.

As for free arginine, the widespread distribution in marine algae have been recorded by many workers ${ }^{4-7)}$ and this fact is also recognized in the present work. Gigartinine, if present, seems to overwhelm arginine in quantity, from the observation that on paper chromatograms gigartinine appears much more distinctly than arginine, although the former is far less sensitive to Sakaguchi's reagent. The quantitative relation between these guanidino compounds will be discussed in detail in the next paper.

In this investigation, the existence of unidentified substances positive for Sakaguchi's reagent was detected in a few species of red algae. A substance of $R_{f} 0.53$, found in $G$. flabelliformis, has been recently isolated and identified as $\gamma$-guanidinobutyric acid, as will be reported in the near future.

\section{Summary}

By means of paper chromatography, the distribution of gongrine, gigartinine and arginine in the extractives of marine algae was investigated. In twenty-five species of marine algae examined, gongrine and gigartinine were found in four species and seven species of red algae, respectively. These guanylurea derivatives were not detected in green and brown algae except one species of brown alga which gave a doubtful spot of gigartinine.

Thanks are due to Mr. K. FUJIMoto for his technical assistance.

\section{References}

1) K. ITo and Y. HASHIMoto: Agr. Biol. Chem., 29, $832 \sim 835$ (1965).

2) K. ITo and Y. HASHIMOTO: This Bull., 32, 274 279 (1966).

3) R. J. Block, E. L. DurRum, and G. ZWEIG: A Manual of Paper Chromatography and Paper Electrophoresis, 128 pp., Academic Press Inc. (1957).

4) S. ShibUYA and K. MARISUmi: Seikagaku, 25, 210 213 (1953).

5) S. Shibuya, K. Makisumi, and Y. Fujita: Ibid, 27, 570 574 (1955).

6) C. OGino: J. of the Tolkyo University of Fisheries, 41, 107 152 (1955).

7) E. J. Lewis and E. A. Gonzalves: Ann. of Botany, 26, 301 316, 317 327 (1962). 